\title{
Exploring Bullying in Nigerian Secondary School and School Administrators Strategies for Its' Management Department of Educational Administration and Policy Studies
}

\author{
Asiyai, Romina Ifeoma \\ Faculty of Education, Delta State University Abraka, Nigeria \\ Email: asiyairomina@yahoo.com
}

Doi:10.5901/jesr.2015.v5n2p305

\begin{abstract}
This study examined bullying in secondary schools in Nigeria. Six research questions were asked and answered using simple percentage and bar charts. A sample of 120 students and 224 staff participated in the study. Interview and questionnaire were the sources of data collection. Findings emerging from analyzed data revealed the common types of bullying in boarding and day schools to include hitting/flogging and extortion. Findings further revealed that the level of bullying was higher among boys than girls and that bullying often occurred in boarding schools than day schools. Findings also showed that the effects of bullying were very dangerous as it results in making students hate going to school, isolation and fearful looking. The effective strategies for managing bullying were identified to include use of school rules and regulations, making students to take anti bullying oaths and teaching empathy to students. The study concludes by recommending that all stake holders in secondary education should work collaboratively to ensure that the school environment is made more students friendly by teaching brotherhood and empathy to students at home, church, society and school.
\end{abstract}

Keywords: Bullying; boys; causes; effects; frequency; girls; management; rate; secondary school; common types.

\section{Introduction}

The school is an institution established for the formal education of the citizens of any country. Students acquire relevant knowledge, skills, positive behavior, competencies, values and abilities for useful living in the society at school. While at school, students socialize with others as they work in groups for their positive development. Positive development of students morally, socially, intellectually, emotionally and physically cannot take place if they do not see the school environment as friendly, safe and secure. However, study by Fajoju (2009) indicated that only few students or pupils can blend harmoniously with their school mates without experiencing violence in school. Bullying is one form of violence that has been threatening the life of students in school in Nigeria. Keashly and Neuman (2010) defined bullying as harassing, offending, excluding someone or negatively affecting someone's work tasks. He continued by saying that bullying has to occur repeatedly and regularly and over a period of time. Bullying is characterized by acts of intentional harm, repeated over time, in a relationship where an imbalance of power exists (Pepler and Craig, 2007; Ma Stewin and Mah, 2001). Bullying is not just a child's play but a terrifying experience faced by many school children every day (Craig, 1998; Beran, 2005; and Thornbery 2010). According to Einarsen, Hoel, Zapf, and Cooper (2003:15), bullying is an escalating process in the course of which the person confronted ends up in an inferior position and becomes the target of systematic negative social acts. All these characteristics are inimical to productive growth and academic development of students. This study examined bullying in Nigerian secondary schools.

\subsection{Statement of the Problem}

The researcher has observed during her visits to schools for teaching practice supervision, several reports of bullying. Students loitering during lesson while some play in nearby compounds refusing to go to school because of fear of being bullied. As noted by Aluede (2006) and Fajoju (2009), the use of guns, knives and other dangerous weapons is now more common than ever in Nigerian school system. This causal observation and several reported cases of bullying in schools prompted this investigation with a view to identify the common types of bullying and the causes, rates of bullying and its effects and school administrators strategies for managing bullying in school so that the environment could become student friendly for their effective learning. 


\subsection{Purpose of the Study}

This study examines bullying in secondary schools. In specific terms, the study intend to:

1. Identify the common types of bullying among day and boarding schools.

2. Find out where bullying often take place among day and boarding students.

3. Find out the extent of bullying among boys and girls.

4. Find out the frequency of bullying among boys and girls.

5. Find out the effects of bullying on students' and their learning.

6. Identify strategies for effective management of bullying.

\subsection{Research Questions}

The study provides answers to six research questions as follows:

1. What are the common types of bullying in day and boarding schools?

2. What is the level of bullying among boys and girls?

3. How frequent does bullying take place among boys and girls?

4. Where does bullying often take place among day and boarding students?

5. What are the effects of bullying on students and their learning?

6. What strategies can be effective in managing bullying in school?

\section{Conceptual Clarification and Literature Review}

Previous studies on bullying suggest that bullying is rampant in school across the globe. Bullying is the intension to cause harms deliberately either physically or emotionally (James, 2010). A child or young person is bullied or picked on when another child or young person or group of children say nasty and unpleasant things to him/her (Olweus, 1999). This two definitions of bullying clearly shows that bullying involves causing harm on a child by another child either physically, emotionally or socially by the use of words. When bullying occurs, it tends to be long standing (Keashly and Neuman, 2010). A study conducted by McKay, Arnold, Fratzl, and Thomas, (2008) on bullying in the academia, they found that $21 \%$ of their sample reported bullying that persisted for more than five years in duration. Bullying involves the use of power by persons who are more powerful, often due to age, physical strength or psychological resilience. A survey conducted in England of 253,755 children and young people of ages 6, 8 and 10 indicates that bullying was widespread. In this study, $60 \%$ of children said they have been bullied in their school (Campbell, 2005). Stay Safe Research, DCSF (2009); Craig and Pepler (1997) and LSYPE (2010) indicates that the type of bullying experienced by boys and girls are of different kind and their reaction to bullying are of different type. Study by Lee and Alexeyev (2008), identified types of bullying as direct, verbal and physical. Stay Safe Research presentation, DCSF (2009) with children and young people in England, Scotland, Wales and Northern Ireland reported that girls felt more at risk from bullying than boys. The study further indicates that girls are more likely to be more victims of name calling and extortion while boys are more likely to see bullying as part of growing up. Study by Van der waal, De Wit, and Hirsing, (2003) revealed that girls were more prone to indirect bullying in the form of social isolation, slandering and rumour spreading while boys tend to be more prone to bullying in the form of physical attack and exhibition of aggressive behavior. A study conducted in Canada cited by Aluede (2011) indicates that 8 to $9 \%$ of elementary school children are bullied frequently while 2 to $5 \%$ of students bully others frequently. Among adolescents at the secondary school level the rates of bullying is higher with 10 to $11 \%$ of students reporting that they have been frequently victimized by their peers and 8 to $11 \%$ reporting that they frequently bully others (Hymel, Rocke-Henderson and Bananno, 2005). The UK office of children commissioner (2006) identified four key characteristics of bullying as:

- Repetitive and persistent

- Intentionally harmful

- Involves an imbalance of power

- Causing feelings of distress, loneliness or lack of confidence.

A study conducted by Einarsen and Mikkelsen (2003), on individual effects of exposure to bullying in workplace, their finding revealed that bullying behavior in higher education involve threats to professional status, isolating and obstruction behaviors such as thwarting the targets ability to obtain important objectives. The report further revealed that bullies exhibit behaviors deigned to undermine their victim's professional standing, authority and competence or impede 
access to key resources for their work. A school with high bullying syndrome scares new students (Ma Xin Len Stewin \& Deveda, 2001; Aluede and Fajoju, 2011; Al Fassi, 2004). Thus bullying can frustrate the victim in many ways, making him/her not to be able to attain his/her goals. Hence Vickers (2001) and Westhues (2004) maintained that the consequences of bullying can be quite damaging to individuals in terms of physical and psychological damage. Bullying has the potential of causing either physical or psychological harm to the victim (Bosworth., Espelage and Simon, 1999). Describing the association between bullies and their victims, Omoke, Afen-Akpaida, 2008 and Thornberg (2010) noted that a single student who bullies can have far reaching effects on the school by creating a climate of fear and intimidation for his/her victims and by standers. Hence Thornberg (2010) lamented that students affected by bullying would be at risk of developing depression, anxiety, mistrust of others, loneliness, low self-esteem, poor social adjustment, poor health and poor academic achievement. Male and female victims of bullying are more likely to exhibit symptoms of suicide (Kaltiala-Heino et al, 1999).

\section{Method and Procedure}

\subsection{Research Design}

This study is a qualitative mixed methods survey research the ex-post-facto design. Mixed methods research utilizes qualitative and quantitative data.

\subsection{Sample and Sampling Technique}

Six secondary schools in Delta North senatorial district of Delta State, Nigeria was sampled, three had boarding facilities while three were day schools. All the schools were mixed (having boys and girls in a single school). Through simple random sampling technique, samples of 120 students and 200 teachers were drawn while purposive sampling technique was employed in selecting 12 principals and 12 counselors. The students were from junior secondary 3 classes. Boys were 60 while girls were 60 . Day students were 60 while boarding students were 60 . Principals, teachers and counselors are used collectively in this study as staff. The overall sample of the study comprised of 344 (120 students and 224 staff). In each school, the interview was conducted with twenty students during break time with due permission from the school authority. The researcher assisted by four persons, visited the schools twice for the interview. The interview questions were later converted to questionnaire for ease of quantitative analysis of data.

\section{Instrument for Data Collection}

The interview and questionnaire were used for the collection of data from the respondents. Questionnaire and interview are the most common way to collect information for mixed method research (McNabb, 2004). The use of interview was to ensure that an in-depth study was made of the phenomenon under investigation. The questionnaire comprised of six parts labeled A-F. Part A consists of items meant to find out the common types of bullying in school. Part B contained items on the level of bullying among boys and girls. Part $C$ contained items which focused on the frequency of bullying among boys and girls, Part D contained items meant to find out where bullying occurs, Part E focused on the effects of bullying while Part $F$ contained items on the effective strategies for managing bullying in school. The questionnaire for Parts $A, B, D, E, F$ were structured on a four point scoring scale of Strongly Agree $(S A)=4$-points, Agree $(A)=3$-points, Disagree $(D)=2$-points and Strongly Disagree $(S D)=1$-point. For part $B$, percentage scores from $70 \%$ and above were taken as High Level $(\mathrm{HL})$, percentage scores from 60 to $50 \%$ was taken as Moderate Level (ML) while percentage score from 49 to $0 \%$ was taken to represent Low Level (LL). While the questionnaire for Part C was structured on a five point Likert scale of Always, A lot, Quite a lot, Sometimes and Never.

\subsection{Instrument Validation and Reliability Determination}

The questionnaire was given face and content validation by experts in educational administration who read through the questions and made useful suggestions which were used to bear on the items before the final draft was typed. The reliability of the instrument was established via test re-test method. The instrument was administered to a sample of 40 made up of junior secondary school students and staff in schools in Abraka which were not used for the study twice within an interval of two weeks. The reliability coefficient computed using Pearson product moment formula yielded an 
index of 0.80 . This shows that the items were internally stable for use. The instrument was administered by the researcher, assisted by four persons trained by her. Two hundred and twenty four and one hundred and twenty copies of questionnaire were administered to staff and students respectively but two hundred and sixteen staff questionnaire and one hundred and fourteen students' questionnaire were retrieved and valid for data analysis.

\subsection{Method of Data Analysis}

Simple percentage was used for data analysis.

\section{Results}

The results of the study are presented in tables below:

Table 1: Identified common types of bullying in schools

\begin{tabular}{|c|c|c|c|c|c|c|c|c|}
\hline \multirow{2}{*}{ Items } & \multicolumn{4}{|c|}{ Day School } & \multicolumn{4}{c|}{ Boarding School } \\
\cline { 2 - 9 } & FA & $\%$ & FD & $\%$ & FA & $\%$ & FD & $\%$ \\
\hline Hitting/Flogging & 34 & 56.6 & 26 & 43.4 & 39 & 65.0 & 21 & 35.0 \\
\hline Kicking & 18 & 30.0 & 42 & 70.0 & 12 & 20.0 & 48 & 80.0 \\
\hline Injuries & 48 & 80.0 & 12 & 20.0 & 35 & 58.3 & 25 & 41.6 \\
\hline Extortion & 16 & 26.7 & 44 & 73.3 & 51 & 85.0 & 09 & 15.0 \\
\hline Threatening & 39 & 65.0 & 21 & 35.0 & 47 & 78.3 & 13 & 21.6 \\
\hline Rumour spreading & 36 & 60.0 & 24 & 40.0 & 35 & 58.3 & 25 & 41.6 \\
\hline Slandering & 28 & 46.6 & 32 & 53.3 & 33 & 55.0 & 27 & 45.0 \\
\hline Name calling & 34 & 56.6 & 26 & 43.4 & 40 & 66.6 & 20 & 33.3 \\
\hline
\end{tabular}

From the data in table 1, the common types of bullying in day schools are hitting/ flogging (56.6\%), injuries (80\%), threatening (65\%), rumour spreading $(60 \%)$ and name calling (56.6\%). While the common types of bullying in boarding schools are hitting/flogging (65\%), injuries (58.3\%). extortion (85\%), threatening (78.3\%) rumour spreading (58.3\%). slandering (55\%) and name calling (66.6\%).

Table 2: Rate/Level of bullying among boys and girls

\begin{tabular}{|c|c|c|c|c|c|c|c|c|}
\hline \multirow{2}{*}{ Items } & \multicolumn{4}{|c|}{ Boys } & \multicolumn{4}{c|}{ Girls } \\
\cline { 2 - 9 } & FA & $\% /$ Level & FD & $\%$ & FA & $\% /$ Level & FD & $\%$ \\
\hline Hitting/flogging & 26 & $43.3, \mathrm{LL}$ & 34 & 56.6 & 13 & $21.6, \mathrm{LL}$ & 47 & 78.3 \\
\hline Kicking & 23 & $38.3, \mathrm{LL}$ & 37 & 61.6 & 11 & $18.3, \mathrm{LL}$ & 49 & 81.6 \\
\hline Extortion & 43 & $71.6, \mathrm{HL}$ & 17 & 28.3 & 35 & $58.3, \mathrm{ML}$ & 25 & 41.6 \\
\hline Injuries & 42 & $70.0, \mathrm{HL}$ & 18 & 30.0 & 22 & $36.6, \mathrm{LL}$ & 38 & 63.3 \\
\hline Threatening & 49 & $81.6, \mathrm{HL}$ & 11 & 18.3 & 40 & $66.6, \mathrm{ML}$ & 20 & 33.3 \\
\hline Rumour spreading & 21 & $35.0, \mathrm{LL}$ & 39 & 65.0 & 38 & $63.3, \mathrm{ML}$ & 22 & 36.6 \\
\hline Slandering & 14 & $23.3, \mathrm{LL}$ & 46 & 76.6 & 34 & $56.6, \mathrm{ML}$ & 26 & 43.3 \\
\hline Name calling & 42 & $70.0, \mathrm{HL}$ & 18 & 30.0 & 41 & $68.3, \mathrm{ML}$ & 19 & 31.6 \\
\hline
\end{tabular}


Fig 1: Bar chart showing Rate/Level of bullying among boys and girls

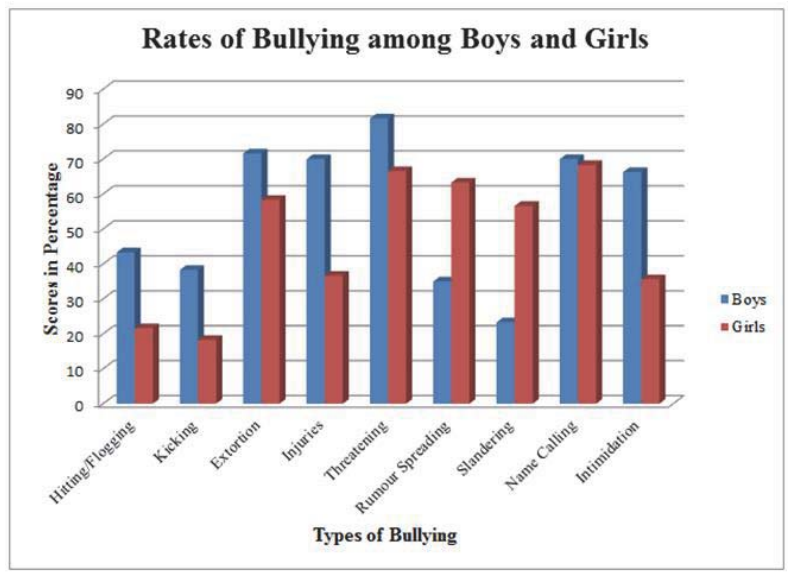

From table 2 and Fig 1, for hitting/flogging, boys recorded 43.3\% while girls recorded 21.6\%. Boys recorded 38.3\% for kicking while girls recorded $18.3 \%$, extortion boys recorded $71.6 \%$ while girls recorded $58.3 \%$, injuries boys recorded $70 \%$ while girls recorded $36.6 \%$, threatening boys recorded $81.6 \%$ while girls is $66.6 \%$, for rumour spreading, boys recorded $35 \%$ while girls recorded $63.3 \%$, for slandering, boys recorded $23.3 \%$ but girls recorded $56.6 \%$ and for name calling, boys recorded $70 \%$ while girls recorded $68.3 \%$. Thus kicking, extortion, injuries, threatening and name calling are more common with boys than girls. But rumour spreading and slandering are more common with girls than boys.

Table 3: Frequency of bullying among boys and girls

\begin{tabular}{|c|c|c|c|c|}
\hline \multirow{2}{*}{ Responses } & \multicolumn{2}{|c|}{ Boys } & \multicolumn{2}{c|}{ Girls } \\
\cline { 2 - 5 } & Score & $\%$ & Score & $\%$ \\
\hline Always & 100 & 42.3 & 98 & 21.2 \\
\hline A lot & 180 & 76.2 & 125 & 52.9 \\
\hline Quite a lot & 148 & 62.7 & 144 & 50.4 \\
\hline Sometimes & 125 & 48.0 & 108 & 45.7 \\
\hline Never & 66 & 27.9 & 78 & 33.0 \\
\hline
\end{tabular}

Fig 2: Bar chart showing frequency of bullying among boys and girls

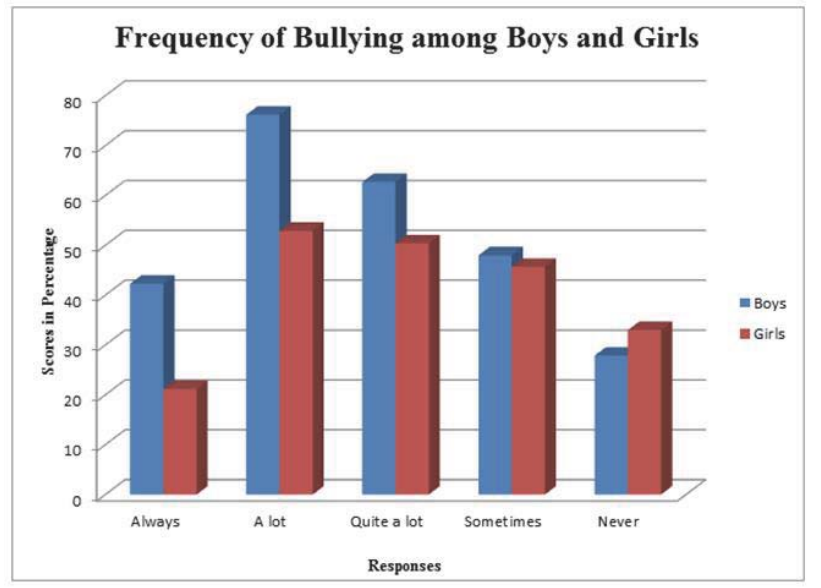

From table 3 and Fig 2, always for boys is $42.3 \%$ and $21.2 \%$ for girls, a lot for boys is $76.2 \%$ and $52.9 \%$ for girls, quite a lot for boys is $62.7 \%$ and $50.4 \%$ for girls, sometimes for boys is $48.0 \%$ and $45.7 \%$ for girls while never for boys is $27.9 \%$ and $33.0 \%$ for girls. Thus, it can be said that bullying is more frequent with boys than girls. 
Table 4: Where bullying often takes place

\begin{tabular}{|c|c|c|}
\hline Responses & Score & $\%$ \\
\hline In the classroom & 218 & 47.8 \\
\hline In the hostels & 324 & 71.0 \\
\hline On the way back from school & 234 & 51.3 \\
\hline In the sport field & 274 & 60.0 \\
\hline
\end{tabular}

From table 4, indicates that bullying often take place in the hostel (71.0\%), in the sports field (60.0\%), on the way to and from school (51.3\%) and in the classroom recorded $47.8 \%$. It is clear that bullying occurs more with boarding schools than day schools since the table 4 indicates that $71 \%$ of bullying takes place in the hostel.

Table 5: Effects of bullying on students and their learning

\begin{tabular}{|l|c|c|c|c|c|}
\hline \multirow{2}{*}{ Items } & \multicolumn{2}{|c|}{ Staff } & \multicolumn{2}{c|}{ Students } & Remark \\
\cline { 2 - 6 } & Score & $\%$ & Score & $\%$ & \\
\hline Bullying can make a student fearful looking in school & 624 & 72.2 & 330 & 72.3 & Agreed \\
\hline A student who is often bullied can stay in isolation always & 728 & 84.2 & 346 & 75.8 & Agreed \\
\hline Bullying can trigger non attendance at school among students & 530 & 61.3 & 322 & 70.6 & Agreed \\
\hline Frequent complaints of being sick & 232 & 26.8 & 218 & 47.8 & Disagreed \\
\hline Bullying can make a student to be always looking unhappy & 508 & 58.7 & 274 & 60.0 & Agreed \\
\hline Bullying can make a student to hate going to school to learn & 521 & 60.3 & 304 & 66.6 & Agreed \\
\hline Bullying can make a student to always ask for extra money from parents & 567 & 65.6 & 280 & 61.4 & Agreed \\
\hline A bullied student can have unexplained bruises on the body & 670 & 77.5 & 324 & 71.0 & Agreed \\
\hline Bullying can make a student to complain frequently of missing items & 722 & 83.5 & 358 & 78.5 & Agreed \\
\hline
\end{tabular}

From table 5, all the items except one are the effects of bullying as perceived by staff and students. These effects are $72.2 \%$ staff and $72.3 \%$ students said that bullying can result to fearful looking, $84.2 \%$ staff and $75.8 \%$ students are of the view that bullying can lead to isolation, $61.3 \%$ staff and $70.6 \%$ students said that bullying can result to students non attendance at school, $58.7 \%$ staff and $60 \%$ students said that bullying can make a student to always look unhappy, $60.3 \%$ staff and $66.3 \%$ students said that bullying can make a student to hate going to school, $65.5 \%$ staff and $61.4 \%$ students said that bullying can make students to always ask for extra money from parents, $77.5 \%$ staff and $71.0 \%$ students are of the opinion that bullying can result to the appearance of unexplained bruises on students body while $83.5 \%$ staff and $78.5 \%$ students said that bullying can make a student to frequently complain of missing items.

Table 6: Effective strategies for managing bullying in school

\begin{tabular}{|l|c|c|c|c|c|}
\hline \multirow{2}{*}{ Items } & \multicolumn{2}{|c|}{ Staff } & \multicolumn{2}{c|}{ Students } & \multirow{2}{*}{ Remark } \\
\cline { 2 - 5 } & Scores & $\%$ & Scores & $\%$ & \\
\hline Use of school rules and regulations & 728 & 84.2 & 320 & 70 & Agreed \\
\hline Teaching empathy & 715 & 82.7 & 312 & 68.4 & Agreed \\
\hline Use of school hot spots to detect bullies & 722 & 83.5 & 298 & 65.3 & Agreed \\
\hline Reporting cases of bullying to PTA & 732 & 84.7 & 286 & 62.7 & Agreed \\
\hline Suspension of bullies & 258 & 29.8 & 233 & 51.0 & Disagreed \\
\hline Use of modeling to teach bullies positive behavior & 688 & 79.6 & 275 & 60.3 & Agreed \\
\hline Students to take anti bullying oaths & 540 & 62.5 & 284 & 61.1 & Agreed \\
\hline $\begin{array}{l}\text { Place fliers on bullying in classroom walls, hostels and on trees in the } \\
\text { school compound }\end{array}$ & 735 & 85.0 & 290 & 63.5 & Agreed \\
\hline Use of corporal punishment & 398 & 46 & 198 & 43.4 & Disagreed \\
\hline
\end{tabular}

From table 6 , the effective strategies that can be used to manage bullying in school are $84.2 \%$ staff and $70.0 \%$ students said that bullying can be effectively managed through the use of school rules and regulations, $82.7 \%$ staff and $68.4 \%$ students said that teaching of empathy can help to manage bullying effectively in school, $83.5 \%$ staff and $65.3 \%$ students said that use of school hot spots to detect bullies is an effective strategy for managing bullying, $84.7 \%$ staff and $62.7 \%$ students said that reporting cases of bullying to Parents Teachers' Association (PTA) can be an effective management 
strategy, $79.6 \%$ staff and $60.3 \%$ students said that teaching bullies positive behavior through the use of modeling can be an effective strategy for managing it. $62.5 \%$ staff and $61.1 \%$ students said that bullying can be effectively managed by making students to take anti bullying oaths and $85.0 \%$ staff and $63.5 \%$ students said that placing posters of bullying on classroom and hostels walls as well as on trees in the school compound can help to manage bullying effective in schools.

\section{Discussion of Findings}

The finding of this study for research question one indicates that the common types of bullying in day schools are injuries $(80 \%)$, threatening $(65 \%)$, rumour spreading $(60 \%)$, hitting/flogging $(56.6 \%)$ and name calling (56.6\%). While the common types of bullying in boarding schools are extortion (85\%), threatening (78.3\%), name calling (66.6\%). Hitting/flogging (65\%), injuries (58.3\%). rumour spreading (58.3\%) and slandering (55\%). This finding is in agreement with the finding of Egbochuku (2007) who similarly reported bullying behaviors such as being threatened, kicking, hitting and extortion as types of bullying for public and private schools in Edo state Nigeria.

For research question two, the finding of the study revealed that for threatening (81.6\%), extortion (71.6\%), name calling (70.0\%) and injuries (70.0\%) boys recorded high level while girls recorded for name calling (68.3\%), threatening $(66.6 \%)$, extortion (58.3\%), that is moderate level and injuries (36.6\%) indicating low level. For rumour spreading, boys recorded (35\%) that is low level while girls recorded (63.3\%) representing moderate level. For slandering, boys recorded (23.3\%) indicating low level but girls recorded (56.6\%) indicating moderate level. This findings of this study showed that extortion and name calling were more with boys than girls. This finding contradicts the finding by Stay Safe Research presentation, DCSF (2009) with children and young people in England, Scotland, Wales and Northern Ireland their finding revealed that girls are more likely to be more victims of name calling and extortion.

The result of this study for research question three indicates that bullying is more frequent with boys than girls. This finding corroborates with that of Egbochuku (2007) whose findings indicated that more girls (81\%) accepted being bullied than boys (68\%) while more boys (77\%) accepted bullying others than girls (62\%). However, this finding contradicts that of Stay Safe Research presentation, DCSF (2009) whose finding indicated that boys are more likely to see bullying as part of growing up while girls felt more at risk with bullying. The findings also contradicts that of Burba, Grigaliuniene, Krisaukaityte, Grinkeviciute, and Staceviciene (2010) whose results indicates that the frequency of bullying was almost equal for boys and girls. The finding also indicates that $48.0 \%$ and $45.7 \%$ boys and girls respectively, said that they have been bullied sometimes. This finding is in agreement with a study conducted in Sheffield, UK cited by McEachern, Kenny, Blake and Aluede (2005) which revealed that $27 \%$ of elementary and middle school children reported being bullied sometimes during the term. Additionally, Hazler et al (1991), Oliver and Thomson (1993) and O'Moore and Hillery (1989), their studies revealed that bullying was more common with boy. For research question four, the finding indicates that bullying often take place in the hostel (71.0\%), in the sports field (60.0\%) and on the way to and from school (51.3\%) in the classroom recorded $47.8 \%$. The implication of this finding is that bullying occurs more with boarding school students than with day school students. This finding is agrees with Zindi (1994) study conducted in Zimbabwe, who revealed that $16 \%$ of boarding school students were bullied now and then while $18 \%$ were bullied more often. However, the findings of this study contradicts the findings of Whitney and Smith (1993), and Siann et al (1993) whose findings indicated that within the school, the play ground is the most common setting for bullying.

Finding for research question five indicated that a good proportion of staff and students $72.2 \%$ and $72.3 \%$ respectively said that bullying can make a student to be fearful looking, while a very significant proportion $84.2 \%$ staff and $75.8 \%$ students are of the view that bullying can lead to isolation with $61.3 \%$ staff and $70.6 \%$ students saying that bullying can result to students non attendance at school. When students hate going to school and do not attend school as a result of fear of being bullied their education is in danger as their academic development will be seriously hampered. In addition, the result of this study revealed that bullying results in a student isolating from other students and make a student to always look unhappy. This behavior can have serious impact on the emotional development of the bullied student as he/her may begin to develop depression and low self-esteem. In agreement with this findings, Thornberg (2010) lamented that students affected by bullying would be at risk of developing depression, anxiety, mistrust of others, Ioneliness, low self-esteem, poor social adjustment, poor health and poor academic achievement. The findings of this study on bullying capable of making students not to attend school corroborates that of Alika (2012) whose finding showed that a significant relationship existed between bullying and drop out from school. Furthermore, the findings revealed that bullying can make students to always ask for extra money from parents. A student who forms the habit of demanding extra money from parents in order to give to bullies may end up becoming a liar and may eventually steal money if he/she is not being given by the parents. The finding also revealed that $77.5 \%$ staff and $71.0 \%$ students are of the 
opinion that bullying can result to the appearance of unexplained bruises on student's body. This could be the reason why Vickers (2001) and Westhues (2004) noted that the consequences of bullying can be quite damaging to individuals in terms of physical, psychological and emotional damage. When children continue to miss the items they already have because of such items being forcefully taken from them by bullies, they suffer in school especially when the items are needed for their academic use. Some of the students find it difficult to tell their parents and may continue to suffer lack in school. All these negatively impact on their academic growth and development.

For research question six, the findings showed that effective strategy for managing bullying are the use of school rules and regulation, teaching of empathy, use of school hot spots to detect bullies, reporting cases of bullying to parents teachers' association, teaching bullies positive behavior through the use of modeling, teaching empathy to bullies, making students to take anti bullying oaths and placing posters of bullying on classroom and hostels walls as well as on trees in the school compound.

\section{Conclusion}

This study examined bullying in secondary schools and identified the common types of bullying prevalent in boarding and day schools, the level of bullying and the frequency of its occurrence among boys and girls. The results of the study indicated that bullying is very dangerous as it has devastating effects on students, their attitude towards school and their learning. Bullying has been found to affect the social, physical, intellectual and emotional development of students. The strategies for effective management of bullying were identified.

\section{Recommendations}

Based on the findings of this study, the following policy suggestions have been recommended for effective school administration:

1. Principals should emphasize the teaching of brotherhood and love by regularly admonishing students during early morning school assembly. They should continue to emphasize to senior students to see the junior students as their brothers

2. Principals should ensure that teachers constantly teach empathy to students both during instruction and during club activities. Senior students should be taught to always put themselves in the position of their junior students

3. Principals should appoint matrons and patrons among teachers and provide accommodation for them within the school premises so that they can constantly monitor boarding students to check bullying among them.

4. Upon admission into boarding students should be made to take anti bullying oaths and be regularly reminded of the oaths they took.

5. Principals should establish laws against bullying and any student found guilty of bullying should be punished accordingly.

6. Principals should ensure that fliers or posters of bullying are placed in hostel walls, classroom walls and on trees round the school compound as indicators to teach bullying to students.

7. Prevention of all forms of bullying should involve all stakeholders so as to create positive learning environment in school.

\section{References}

Alika, H. I. (2012). Bullying as a correlate of drop out from school among adolescents in Delta State: implication for counseling. Education, 132(2),

Aluede, O. and Fajoju, A. S. (2011). Bullying behavior among secondary school students in Benin metropolis of Edo State Nigeria, Zimbabwe Journal of Educational Research, 23 (2), 102-119. Retrieved from www.academia.edu/116(accessed March 12 2013).

Al Fassi, M. (2004). Effect of a learner centered environment on the academic competence and motivation of students at risk, Learning Environment Research, 7, 1-22.

Beran, T. (2005). A new perspective on managing bullying in school: pre-service teacher's attitudes, Journal of Social Sciences (Special Issue) 8, 43-49.

Bosworth, K., Espelage, L. D. and Simon, T. (1999). Factors associated with bullying behavior in middle school students, Journal of Early Adolescence, 19, 341-362.

Burba, B., Grigaliuniene, V., Krisaukaityte, A. Grinkeviciute, A. and Staceviciene, R. (2010). Economic and psychosocial impact on bullying I schools of Kaunas. European Psychiatry, 25(1),387. 
Campbell, M. A. (2005). Cyber bullying: An old problem in a new guise? Australian Journal of Guidance and Counseling 15(1), 68-76. Retrieved from eprints.gut.edu.au/1925/01.

Craig, W. (1998). The relationship among bullying, depression, anxiety and aggression among elementary school children, Personality and Individual Differences, 24, 123-130.

Egbochuku, E. O (2007). Bullying in Nigerian schools: prevalence study and implications for counseling, Journal of Social Sciences, 14, 65-71.

Fajoju, A. S. (2009). School bullying and academic performance of secondary school students in Edo State, Doctoral Thesis, Ambrose Ali University, Ekpoma, Nigeria.

Einarsen, S. and Mikkelsen, E. G. (2003). Individual effects of exposure to bullying at work. In S. Einarsen, H. Hoel, D. Zapf and C. L. Cooper (eds), Bullying and emotional abuse in the workplace: International perspectives in research and practice 127-144, London: Taylor and Francis.

Hazler, R. J., Hoover, J. H and Oliver, R. (1991). Student perception of victimization by bullies in schools, Journal of Humanistic Education and Development, 29, 143-150.

Hymel, S., Rocke-Hendereson, N. and Bonanno, R. A. (2005). Moral disengagement: A framework for understanding bullying among adolescences, Journal of Social Sciences, (Special Issue), 8, 1-11.

Keashly, L. and Neuman, J. H. (2010). Faculty experiences with bullying in higher education: Causes, consequences and management, Administrative Theory and Praxis, 32 (1), 48-70. Retrieved from www.ccas.net/files/advance/keashly_bullying.pdf

Lee, A. B. and Alexeyev, E. B. (2008). The problem of school bullies: what the research tells us. Adolescence, 43(169), 1-11.

Ma, Xin, Len L. Stewin and Deveda, Mah (2001). Bullying in school: nature, effects and remedies, Research Papers in Education, 16 (3), 241-270.

McEachern, et al (2005). Bullying in schools: International variations, Journal of Social Sciences (Special Issue) 8, 51-58.

McKay, et al (2008). Workplace bullying in academia: A Canadian study, Employee Responsibilities and Rights Journal, 20, 70-100.

O'Moore, A. M. and Hillery, B. (1989). Bullying in Dublin schools, Irish Journal of Psychology, 10 (3), 426-441.

Pepler, D. J. and Craig, S. (2007). Binoculars on bullying: a new solution to protect and connect children, York University and the Hospital for Sick Children. Retrieved from http://www.voicesforchildren.ca/report-feb2007-1-htm.

Rivers, I. and Smith, P. K. (1994). Types of bullying and their correlates, Aggressive Behavior, 20, 359-368.

Siann, G. M., Callaghan, R., Lockhart, and Rawson, L. (1993). Bullying: teachers views and school effects, Educational Studies, 20, 359-368.

Vickers, M. H. (2001). Bullying as unacknowledged organizational evil: A researcher's story, Employee Responsibilities and Rights Journal, 13, 205-217.

Van der waal, et al (2003). Psychological health among young offenders of direct and indirect bullying, Pediatrics, 111, $1312-1312$.

Westhues, K. (2004). Workplace mobbing in academia: Reports from twenty universities. Lewiston, New York; Edwin Mellen Press.

Zapf, D. and Einarsen, S. (2003). Individual antecedents of bullying: Victims and perpetrators. In S. Einarsen, H. Hoel, D. Zapf \& C. L. Cooper (eds), Bullying and emotional abuse in the workplace: International perspectives in research and practice 165-184, London: Taylor and Francis.

Zindi, F. (1994). Bullying at boarding school: A Zimbabwe study, Research in Education, 51, 23-32. 
